\title{
Whole blood targeting and activation of monocytes with TLR7 agonist formulated in cationic liposomes
}

\author{
Simon S Jensen ${ }^{1 *}$, Pia T Johansen ${ }^{1}$, Daniel Zucker ${ }^{2}$, Jonas Henriksen², Thomas Andresen², Alcide Barberis ${ }^{3}$, \\ Roberto $\mathrm{Maj}^{3}$, Houman Pourhassan ${ }^{1}$, Jeanette Wern' ${ }^{1}$, Monika Gad ${ }^{1}$
}

From Society for Immunotherapy of Cancer 28th Annual Meeting

National Harbor, MD, USA. 8-10 November 2013

Monocytes are one of the major phagocytic cells in the periphery that patrols the circulation for invading pathogens, and upon activation differentiates into dendritic cells, capable of migration to lymph nodes eliciting an adaptive immune response. Monocytes has for more than a decade been precursor cell for generation of autologous dendritic cell cancer vaccines, but clinical results have shown limiting benefits for the patients. One way of improving dendritic cell vaccines is targeting the monocytes in vivo with a suitable carrier of adjuvant together with tumor antigens, to boost monocyte differentiation towards tumor antigen presenting DCs. Here we report a novel monocyte targeting liposome technology capable of delivering TLR7 agonist to CD14 positive monocytes in fresh whole human blood. Liposomes with a positive surface charge were able to specifically target monocytes over lymphocytes and granulocytes, and showed association with $90-100 \%$ of the monocytes. Formulation of the TLR7 agonist in monocyte targeting liposomes showed strong activation of the monocytes, with potent induction of proinflammatory cytokines, and differentiation into tissue inflammatory DCs, demonstrating that the liposomes are able to deliver compounds to the endosomes where TLR7 is present. The present monocyte targeting technology may be a promising approach for designing cancer vaccines with suitable adjuvants and cancer antigens.

\section{Authors' details}

${ }^{1}$ Immune Cell Targeting, Bioneer, Hoersholm, Denmark. ${ }^{2}$ Depertment of Micro and Nanotechnology, DTU Nanotech, Lyngby, Denmark. ${ }^{3}$ Telormedix, Bioggio, Switzerland.

'Immune Cell Targeting, Bioneer, Hoersholm, Denmark

Full list of author information is available at the end of the article
Published: 7 November 2013

doi:10.1186/2051-1426-1-S1-P130

Cite this article as: Jensen et al: Whole blood targeting and activation of monocytes with TLR7 agonist formulated in cationic liposomes. Journal for ImmunoTherapy of Cancer 2013 1(Suppl 1):P130.

Submit your next manuscript to BioMed Central and take full advantage of:

- Convenient online submission

- Thorough peer review

- No space constraints or color figure charges

- Immediate publication on acceptance

- Inclusion in PubMed, CAS, Scopus and Google Scholar

- Research which is freely available for redistribution

○ 2013 Jensen et al; licensee BioMed Central Ltd. This is an Open Access article distributed under the terms of the Creative Commons 